\title{
50 ÉVES A FELSŐFOKÚ TANÍTÓ- ÉS ÓVÓKÉPZÉS
}

A tanító- és óvóképzés szakmai szervezetei 2009. október 16-án a Magyar Tudományos Akadémián tudományos ülést rendeztek a tanító- és óvóképzés felsőfokúvá válásának félévszázados évfordulójára emlékezve. Szándékuk szerint felidézték azt a folyamatot, amelynek során a korábban nép-, illetve közoktatási igényeket szolgáló és a közoktatás rendszerébe illeszkedő iskolatípusból a felsőoktatási (főiskolai, majd egyetemi) struktúra organikus része lett, miközben megőrizte szerves kapcsolatát a közoktatással is (Hunyady Györgyné: Tanítóképzés kettős kötésben). A történet a XIX. század végére nyúlik vissza, amikortól számos kísérlet történt a felsőfokú tanítóképzés megteremtésére. Donáth Péter előadása e törekvések motívumait elemezte a döntéshozók és az érintettek szempontjából (Iskolakultúra, 2010, 2. sz. 86-92. o.). A hosszú ideig érlelödő, majd mégis kissé váratlan döntés 1959-ben a tanítóképzés teljes rendszerét érintette: a középfokú tanítóképző iskolák egy év múlva, 1960-ban adtak ki utoljára érettségi bizonyítványt, s a bázisukon szerveződő felsőfokú intézetekben a küzdelem célja innentől kezdve a szakmai önazonosság megőrzése, az igényes tudományos tevékenység iránti igények felkeltése, a személyi-tárgyi feltételek megteremtése, majd a felsőfokú képzés koncepciózus továbbfejlesztése volt. Az ötven éves történetet Kelemen Elemér tanulmánya („Nem középiskolás fokon...”. Felsőfokú tanítóképzésünk ötven éve (1959-2009) négy periódusra bontva tárgyalja. A felolvasó ülésen a szervezeti-jogi keretek változás-története mellett kísérlet történt a felsőfokú képzés gyakorlati pedagógiájának bemutatására is: egyfelől előadás hangzott el az eötvösi hagyományokra visszanyúló gyakorlóiskoláknak a pálya gyakorlati müvelésére felkészítő szerepéről (Cseh Béla: A gyakorlóiskolák 50 esztendejéröl), másfelöl Barsi Ernö, a győri felsőfokú tanítóképző intézet első tanári karának tagja, ma is tevékeny és hatékony tanára, emlékezett vissza a kezdetekre: a magas színvonalú zenei képzés megőrzendö hagyományára, a tanítóképzők tanárainak és diákjainak zenei s a belőle kinőtt néprajzi értékmentő tevékenységére (Emlékeim a győri Felsőfokú Tanítóképző kezdeti éveiből).

A felsőfokú óvóképzés ötven éve sok tekintetben párhuzamosan haladt a tanítóképzésével. Nemcsak a gyakran közös képző helyekből, hanem legalább annyira a közös szakmai érdekekből, a felkészítés hasonló, illetve komplementer vonásaiból is fakadóan. A felsőfokú óvóképzés öt évtizedes múltjának felidézésére $S z a-$ kács Mihályné vállalkozott. Előadásában a történeti múlt felidézése során mérföldkövekhez hasonlította a sorsfordító eseményeket, történéseket, amelyek az utazó számára jelzik a megtett távolságokat $\mathrm{s}$ a célbaérésig még rá váró mérföldeket. (Mérföldkövek I-II-III. A Kisgyermek 2009, 4. sz..; 2010, 1., 2. sz,)

A „bolognai folyamatból” származó nagy szerkezeti változások már a felsőoktatásba integrálódott tanító-, óvóképzést érintették. A hatások ezért részben na- 
gyon hasonlóak a más típusú intézményekben észlelt változásokhoz, részben viszont nagyon is egyediek, mivel ezek a szakterületek ismét speciális helyzetbe kerültek: az alapképzés náluk nem egyszerúen három(négy) évnyi tanulást jelent felsőfokon, hanem egy pedagógus-szakmára való konkrét felkészülést is, hallgatóik végzettségükkel elhelyezkedhetnek óvodapedagógusként, tanítóként, de tovább is tanulhatnak mester szakon. Erről a nagyon izgalmas periódusról Kovácsné Bakosi Éva készített elemző tanulmányt (Az óvóképzés és a bolognai folyamat).

A Pedagógusképzés folyóirat születésétől kezdve figyelemmel kísérte a tanító-, óvóképzés területén zajló változásokat, így vált a későbbi krónikások egyik fontos forrásává is. A lap őrizve ezt a hagyományát az alábbiakban közreadja az ötven éve felsőfokúvá vált tanító- és óvóképzés ünnepi ülésén elhangzott előadások szerkesztett (és másutt még meg nem jelent) változatát.

(Hunyady Györgyné) 